\title{
Endocannabinoids Regulate the Migration of Subventricular Zone-Derived Neuroblasts in the Postnatal Brain
}

\author{
Madeleine J. Oudin, Sangeetha Gajendra, Gareth Williams, Carl Hobbs, Giovanna Lalli, and Patrick Doherty \\ Wolfson Centre for Age-Related Diseases, King's College London, London SE1 1UL, United Kingdom
}

In the adult brain, neural stem cells proliferate within the subventricular zone before differentiating into migratory neuroblasts that travel along the rostral migratory stream (RMS) to populate the olfactory bulb with new neurons. Because neuroblasts have been shown to migrate to areas of brain injury, understanding the cues regulating this migration could be important for brain repair. Recent studies have highlighted an important role for endocannabinoid $(\mathrm{eCB})$ signaling in the proliferation of the stem cell population, but it remained to be determined whether this pathway also played a role in cell migration. We now show that mouse migratory neuroblasts express cannabinoid receptors, diacylglycerol lipase $\alpha$ (DAGL $\alpha$ ), the enzyme that synthesizes the endocannabinoid 2-arachidonoylglycerol (2-AG), and monoacylglycerol lipase, the enzyme responsible for its degradation. Using a scratch wound assay for a neural stem cell line and RMS explant cultures, we show that inhibition of DAGL activity or $\mathrm{CB}_{1} / \mathrm{CB}_{2}$ receptors substantially decreases migration. In contrast, direct activation of cannabinoid receptors or preventing the breakdown of 2-AG increases migration. Detailed analysis of primary neuroblast migration by time-lapse imaging reveals that nucleokinesis, as well as the length and branching of the migratory processes are under dynamic control of the eCB system. Finally, similar effects are observed in vivo by analyzing the morphology of green fluorescent protein-labeled neuroblasts in brain slices from mice treated with $\mathrm{CB}_{1}$ or $\mathrm{CB}_{2}$ antagonists. These results describe a novel role for the endocannabinoid system in neuroblast migration in vivo, highlighting its importance in regulating an additional essential step in adult neurogenesis.

\section{Introduction}

In the adult brain, neural stem (NS) cells proliferate in the subventricular zone (SVZ) and generate neuroblasts that migrate along the rostral migratory stream (RMS) to populate the olfactory bulb with new neurons (Alvarez-Buylla et al., 2000). Importantly, neuroblasts can also divert away from the RMS and migrate to damaged areas in the brain in which they might limit damage and/or restore function (Arvidsson et al., 2002; Goings et al., 2004; Zhang et al., 2007). In-depth knowledge of the factors that regulate neuroblast migration is therefore essential to facilitate translational research in this area.

Cell adhesion molecules (CAMs), such as neural cell adhesion molecule (NCAM) (Ono et al., 1994; Hu et al., 1996), matrix metalloproteinases (Bovetti et al., 2007; Murase et al., 2008), the ephrin family of receptor tyrosine kinases (Conover et al., 2000; Anton et al., 2004), and growth factors such, as BDNF (Chiaramello et al., 2007), hepatocyte growth factor (Garzotto et al.,

Received Oct. 20, 2010; revised Jan. 6, 2011; accepted Jan. 12, 2011.

This work was supported by the Biotechnology and Biological Sciences Research Council. We thank Jennifer Shieh for her valuable advice on RMS explant cultures, Dr. Masaru Okabe for the pCX-EGFP plasmid, Dr. Alain Chedotal as well as Athena Ypsilanti for their help in learning the in vivo electroporation technique, and Dr. Bia Goncalves for her help with the injections. We thank Dr. Maurice Elphick for the $\mathrm{CB}_{1}$ antibody, Dr. Ken Mackie for the $\mathrm{CB}_{1}$ and MAGL antibodies, Dr. Masahiko Watanabe for the DAGL $\alpha$ antibody, Dr. Tarek Samad for tissue from the MAG lipase knock-out mouse, and Dr. Ben Cravatt's laboratory for the MAGL inhibitor. Finally, we thank Drs. Giorgio Ortar and Vincenzo Di Marzo for providing us with the novel DAGL inhibitor, OMDM188.

Correspondence should be addressed to Prof. Patrick Doherty, Wolfson Centre for Age-Related Diseases, King's College London, London SE1 1UL, UK. E-mail: Patrick.Doherty@kcl.ac.uk.

DOI:10.1523/JNEUROSCI.5483-10.2011

Copyright $\odot 2011$ the authors $\quad 0270-6474 / 11 / 314000-12 \$ 15.00 / 0$
2008), glial cell line-derived neurotrophic factor (Paratcha et al., 2006), vascular endothelial growth factor (Zhang et al., 2003), and IGF-1 (Hurtado-Chong et al., 2009), can regulate neuroblast migration. Many of these molecules have the potential to crosstalk to endocannabinoid (eCB) signaling pathways in cells. For example, eCB signaling couples NCAM and FGF receptor signaling to axonal growth (Williams et al., 2003), a migratory response that functions at the level of the neuronal growth cone. eCB signaling also regulates the migration of many cell types, including immune (Miller et al., 2008), hematopoietic (Jordà et al., 2002; Patinkin et al., 2008), and cancer (Joseph et al., 2004; Preet et al., 2008) cells. Interestingly, the eCB pathway is also often upregulated after brain injury (Mechoulam et al., 2007). This clearly appears to be an adaptive pathway with the potential to integrate a number of extracellular signals to migratory responses.

There is an emerging consensus that $\mathrm{eCB}$ signaling plays a major role in adult neurogenesis. In this context, substantial reductions in NS cell proliferation are seen in both the hippocampus and SVZ when $\mathrm{CB}_{1}$ and/or $\mathrm{CB}_{2}$ receptor function is inhibited by selective antagonists (Jin et al., 2004; Aguado et al., 2005; Jiang et al., 2005; Palazuelos et al., 2006; Goncalves et al., 2008). Similar effects are seen when diacylglycerol lipases, DAGL $\alpha$ or DAGL $\beta$, the enzymes that synthesize 2-arachidonoylglycerol (2-AG) (the major eCB in the brain), are knocked out (Gao et al., 2010) or inhibited by RHC80267 (O,O'[1,6-hexanediylbis(iminocarbonyl)] dioxime cyclohexanone) or tetrahydrolipstatin (THL) (Goncalves et al., 2008). Whereas eCB function has been investigated in NS cell proliferation, a direct role in other important steps in adult neurogenesis such as stem cell-derived neuroblast migration has not been investigated. 
Here, we show that eCB signaling is required for the migration of an NS cell line in a wound closure assay and for the migration of neuroblasts out of cultured RMS explants. Targeting the $\mathrm{eCB}$ system markedly affects nucleokinesis and causes dramatic changes in the number and length of processes extending from neuroblasts. Importantly, inhibiting $\mathrm{eCB}$ receptor function in vivo produces similar effects on the morphology of migratory neuroblasts within the RMS.

\section{Materials and Methods}

Animals. Both male and female CD-1 mice were used (Charles River) in these studies. All procedures were performed in accordance with United Kingdom Home Office Regulations (Animal Scientific Procedures Act, 1986).

Cell lines. Protocols used for the culture of NS cells have been described in detail previously (Conti et al., 2005). In this study, we used COR-1 cells that are derived from mouse fetal cortex. Briefly, cells were expanded as adherent cultures on gelatin-coated flasks (Iwaki) in Euromed-N media (Euroclone) supplemented with N2 (Invitrogen) and $10 \mathrm{ng} / \mathrm{ml}$ each of epidermal growth factor and FGF-2 (Peprotech).

Scratch wound assay. Briefly, COR-1 cells were grown in normal growth media and plated out on Essen Image Lock 24-well plates at 600,000 cells per well. After $24 \mathrm{~h}$, confluent cell layers were scratched using the Essen Woundmaker to create a cell-free wound $\sim 800-900 \mu$ m wide. After scratching, cells were treated with various drugs in normal growth media, including a $\mathrm{CB}_{1}$ antagonist (AM251 [N-1-(2,4-dichlorophenyl)-5-(4-iodophenyl)-4methyl- $N$-1-piperidinyl-1 $H$-pyrazole-3-carboxamide]) $(0.25-1 \mu \mathrm{M}), \mathrm{a} \mathrm{CB}_{2}$ antagonist (JTE-907 [ $\mathrm{N}$-(benzo[1,3] dioxol-5-ylmethyl)-7-methoxy-2-oxo8-pentyloxy-1,2-dihydroquinoline-3-carboxamide]) (0.25-1 $\mu \mathrm{M})$, a $\mathrm{CB}_{1}$ agonist (ACEA [arachidonyl-2' -chloroethylamide/(all Z)- $\mathrm{N}$-(2-cycloethyl)5,8,11,14-eicosatetraenamide]) $(0.25-1 \mu \mathrm{M})$, and a $\mathrm{CB}_{2}$ agonist (JWH-133 [3-(1919dimethylbutyl)-1-deoxy-D8-tetrahydrocannabinol]) (0.25-1 $\mu \mathrm{M})$, well-characterized drugs that are selective for their targets (Pertwee, 2006), and the DAGL inhibitors RHC80267 (10-50 $\mu \mathrm{M})$ and THL (5-10 $\mu \mathrm{M})(\mathrm{Bi}-$ sogno et al., 2003). Drugs were obtained from Tocris Bioscience, and their effects on COR-1 cells, including dose-response curves, have been reported previously (Goncalves et al., 2008). For this reason, we generally show results obtained with the most efficacious concentration of each drug, but representative examples of dose-response curves can be seen in supplemental Figure 1 (available at www.jneurosci.org as supplemental material). The plate was placed into the Incucyte (Essen) in which wound width was measured every $2 \mathrm{~h}$ for $24 \mathrm{~h}$. The rate of migration was obtained by measuring the area under the curve representing the change in wound width over time.

SVZ explant migration assay. Briefly, brains from postnatal day 5 (P5) to P8 CD1 mice were sliced coronally with a tissue chopper and placed in HBSS with 5 mM HEPES and 1\% penicillin-streptomycin (Ward et al., 2005b). Under a high-magnification dissecting microscope (Leica), the RMS was identified by its translucent appearance and was dissected from the surrounding brain tissue. Explants were then cut up into smaller pieces of $\sim 200$ $\mu \mathrm{m}$ in diameter. After being resuspended in Neurobasal medium (containing 30\% glucose, 2 mM L-glutamine, and B27 supplement; all from Invitrogen), explants were embedded in Matrigel (BD Biosciences) diluted 3:1 with fresh Neurobasal medium containing the drug of interest onto glass coverslips. When the Matrigel matrix had solidified (after $\sim 15 \mathrm{~min}$ at $5 \% \mathrm{CO}_{2}$ and $37^{\circ} \mathrm{C}$ ), medium was added containing various drugs targeting the endocannabinoid system essentially as described above but in addition including a third more potent DAGL inhibitor, OMDM188 ( $N$-formyl-L-isoleucine(1S)-1-[[(2S,3S)-3-hexyl-4-oxo-2-oxetanyl] methyl]dodecyl ester) $(0.25$ $\mu \mathrm{M}$ ), a kind gift from Dr. Vincenzo Di Marzo (Istituto di Chimica Biomolecolare, Napoli, Italy) (Ortar et al., 2008), and the monoacylglycerol lipase (MAGL) inhibitor JZL-184 (4-nitrophenyl 4-[bis(1,3-benzodioxol-5yl)(hydroxy)methyl]piperidine-1-carboxylate) $(0.5 \mu \mathrm{M})$, a kind gift from Dr. Ben Cravatt (Scripps Institute, La Jolla, CA) (Long et al., 2009). Explants were maintained for up to $1 \mathrm{~d}$ in vitro at $5 \% \mathrm{CO}_{2}$ and $37^{\circ} \mathrm{C}$.

To obtain cultures of dissociated neuroblasts, RMS explants were triturated in HBSS with $0.25 \mathrm{mg} / \mathrm{ml}$ trypsin (Invitrogen) and $20 \mu \mathrm{g} / \mathrm{ml}$ DNase (Worthington) and plated in Neurobasal medium with supplements on coverslips previously coated with poly-ornithine $(0.5 \mathrm{mg} / \mathrm{ml})$ and laminin $(10 \mu \mathrm{g} / \mathrm{ml})$ (Sigma).
Postnatal electroporation. P3 mice pups, both male and female, were anesthetized with isoflurane $(0.6 \mathrm{~L} / \mathrm{min})$. Using a pulled glass capillary (diameter, $1.5 \mathrm{~mm}$; Clarke Electromedical Instruments), $3 \mu \mathrm{l}$ of $1 \mu \mathrm{g} / \mu \mathrm{l}$ pCX-enhanced green fluorescent protein (EGFP) plasmid (a kind gift from Dr. Masaru Okabe, Osaka University, Osaka, Japan) were injected into the right ventricle. Animals were then subjected to five electrical pulses of $99.9 \mathrm{~V}$ for $50 \mathrm{~ms}$ with $850 \mathrm{~ms}$ intervals using the CUY21SC electroporator (Nepagene) and $5 \mathrm{~mm}$ tweezer electrodes (Sonidel) coated with conductive gel (CEFAR). Animals were then reanimated under oxygen and returned to their mother. Fourteen days later, the pups were injected intraperitoneally with $50 \mu \mathrm{l}$ of a $\mathrm{CB}_{1}$ antagonist, $\mathrm{AM} 251$ or LY320135, or a $\mathrm{CB}_{2}$ antagonist, JTE-907 or AM630, at $5 \mathrm{mg} / \mathrm{kg}$ in $0.8 \%$ DMSO (all drugs from Tocris Bioscience). Twenty-four hours later, the pups were killed and their brains analyzed. Much longer-term treatment of animals with these drugs has no obvious effects on the general morphology of the SVZ, RMS, or olfactory bulb (Goncalves et al., 2008). Visual inspection of tissue sections stained for Hoechst to label all nuclei, GFAP to label astrocytes, or polysialic acid (PSA)-NCAM or doublecortin (DCX) to label neuroblasts from control and drug-treated animals revealed no obvious difference in the general morphology of the RMS or in the expression of these markers (supplemental Fig. 2, available at www.jneurosci.org as supplemental material).

Immunohistochemistry. For the RMS explant migration assays, explants were fixed with $4 \%$ paraformaldehyde (PFA) for $45 \mathrm{~min}, 6 \mathrm{~h}$, or $24 \mathrm{~h}$ after embedding. The explants were blocked in 15\% goat serum/ $0.3 \%$ Triton X-100/PBS for $1 \mathrm{~h}$ and then incubated with Alexa Fluor 488 -phalloidin (1:200; Invitrogen) overnight at $4^{\circ} \mathrm{C}$. The coverslips were then mounted with Mowiol. For the staining of dissociated RMS cultures, cells were fixed with $4 \%$ PFA for $45 \mathrm{~min} 2$ or $5 \mathrm{~d}$ after plating. Cells were blocked with $1 \%$ BSA/0.1\% Triton X-100/PBS for $1 \mathrm{~h}$ and then incubated with the primary antibody overnight at $4^{\circ} \mathrm{C}$ : rabbit anti-DCX (1:100; Abcam), guinea pig anti-DAGL $\alpha$ (1:100; a kind gift from Dr. Masahiko Watanabe, Hokkaido University School of Medicine, Sapporo, Japan) (Yoshida et al., 2006), rabbit anti-CB 1 receptor (1:200; a kind gift from Dr. M. Elphick, Queen Mary, University of London, London, UK), rabbit anti- $\mathrm{CB}_{2}$ receptor (1:500; Cayman Chemical), and goat antiMAGL (1:100; Abcam). The DAGL $\alpha$ antibodies used in the present study specifically label structures involved in eCB signaling with no staining seen throughout the brains of DAGL $\alpha$ knock-out mice (Gao et al., 2010). In the present study, we confirmed DAGL $\alpha$ antibody specificity for cultured cells by showing that the antibodies only stain COS-7 cells after the expression of transfected DAGL $\alpha$ (supplemental Fig. 3, available at www. jneurosci.org as supplemental material). The $\mathrm{CB}_{1}, \mathrm{CB}_{2}$, and the $\mathrm{Abcam}$ MAGL antibodies have also had their specificity validated by use of tissues from knock-out mice (Bridges et al., 2003; Gong et al., 2006) (C.H., unpublished observations). In addition, in the case of DAGL $\alpha$, the $\mathrm{CB}_{1}$ receptor, and MAGL, results presented were verified using independent antibodies obtained from Abcam for DAGL $\alpha$ (Gao et al., 2010) and Dr. Ken Mackie (Indiana University, Bloomington, IN) for the $\mathrm{CB}_{1}$ receptor and MAGL (Twitchell et al., 1997; Straiker et al., 2009). The specificity of these antibodies has also been independently validated for cultured cells (Mulder et al., 2008; Keimpema et al., 2010). After three PBS washes, the appropriate secondary antibodies were added (Alexa Fluor 594 or 488 at 1:1000; Invitrogen) for $2 \mathrm{~h}$ at room temperature. The cells were also stained with Hoechst (1:10,000; Sigma) and in some cases with Alexa Fluor 488-phalloidin (1:200; Invitrogen) for $2 \mathrm{~h}$ at room temperature, washed, and mounted with Mowiol. Images were taken using a confocal microscope (Carl Zeiss LSM 710).

For histological analysis of GFP-labeled neuroblasts, brains were fixed in $4 \%$ PFA overnight and subsequently hemisected. The right side of the brain was mounted in $20 \%$ gelatin (Sigma) and fixed overnight in $4 \%$ PFA. Brains were then cut in $50 \mu \mathrm{m}$ slices on a vibratome (VT10005; Leica) and kept in PBS with $0.1 \%$ sodium azide. For staining, slices were blocked for $1 \mathrm{~h}$ with $1 \%$ BSA/0.1\% Triton X-100/PBS and then incubated with rabbit anti-GFP (1:1000; Invitrogen) overnight at $4^{\circ} \mathrm{C}$. After washing in PBS, slices were incubated with the Alexa Fluor 488 anti-rabbit secondary antibody (1:1000) and Hoechst (1:5000; Sigma) for $3 \mathrm{~h}$ at room temperature and then mounted in Mowiol. Images were taken using a confocal microscope (Carl Zeiss LSM 710). Labeled neuro- 
blasts were sampled throughout the entire length of the RMS, and we found no evidence to suggest regional variations in responsiveness to the treatments.

For immunohistochemical localization of DAGL $\alpha$, PSA-NCAM, and GFAP in the RMS, $5 \mu \mathrm{m}$ paraffin wax coronal sections were used. Sections were first dewaxed in xylene, heated in citric acid (10 mM, pH 6) until boiling, and then washed under running tap for $5 \mathrm{~min}$. Sections were then blocked with $1 \%$ BSA for $15 \mathrm{~min}$, followed by overnight incubation at $4^{\circ} \mathrm{C}$ with the primary antibody: rabbit anti-GFAP (1:3000; Dako), mouse anti-PSA-NCAM (1:600; Sigma), rabbit anti-DCX (1: 1500; Abcam), and guinea pig anti-DAGL $\alpha$ (1:100). The sections were then incubated with the corresponding fluorescent secondary antibody (Alexa Fluor 488 or Alexa Fluor 594; 1:1000; Invitrogen) and/or Hoechst 33342 (1:10,000; Sigma).

Data analysis. To quantify migration out of the explants, pictures were taken on an Apotome microscope (Carl Zeiss). Using NIH Image J, we measured the distance between the edge of the explant and the farthest cell (identified by Hoechst staining) for at least 10 different positions around the explant to obtain the average distance migrated out of each explant. The presented data are obtained from three independent experiments, with at least 10 explants per condition per experiment.

For time-lapse imaging analysis, RMS explants were embedded in Matrigel onto Hi-Q4 multi-experiment dishes (Nikon) and imaged with a Nikon Biostation every $4 \mathrm{~min}$ for $24 \mathrm{~h}$ while at $37^{\circ} \mathrm{C}$ and $5 \% \mathrm{CO}_{2}$. The movies were then analyzed using Volocity Software (PerkinElmer Life and Analytical Sciences).

For analysis of time-lapse imaging of migrating neuroblasts, we examined nuclear movement, process length, and branching. First, the position of the cell nucleus was tracked in each frame to obtain the distance migrated by the nucleus per frame. Each cell was tracked for at least $1 \mathrm{~h}$. Second, the length of any protrusion originating from the cell body was measured for each frame for each cell. The lengths obtained were averaged to calculate the average process length for a given cell over time. Finally, we quantified the number of branching points per cell per timeframe. A branching point can be described as either a protrusion from the cell body or from the leading process itself. For this analysis, at least 40 cells were tracked for each condition, from explants dissected on 3 different days.

For morphological analysis of neuroblasts in brain slices, process length and branching were also examined. The length of the leading process for each cell was measured using NIH Image J. In addition, the number of cells that displayed secondary branching was counted. Secondary branching was defined as a protrusion from the leading process $>1$ somal length from the tip of the growth cone, to differentiate from a branched growth cone (Koizumi et al., 2006). In this experiment, $n=4$ for controls, $n=5$ for AM251- and JTE-907-treated groups, and $n=6$ for AM630- and LY320135 (4-[6-methoxy-2-(4-methoxyphenyl)-1benzofuran-3-carbonyl]benzonitrile)-treated groups, with at least 100 cells analyzed per condition.

Statistical analysis. Student's two-sided $t$ test was used for all statistical analysis. When shown, ${ }^{*} p<0.05,{ }^{* *} p<0.01,{ }^{* * *} p<0.001$ (all relative to control).

\section{Results}

eCB function is required for stem cell migration in culture

The eCB system drives proliferation of NS cells in the adult brain (see Introduction). However, it is not known whether eCB signaling is required for other aspects of adult neurogenesis, such as stem cell and/or neuroblast migration. The recently characterized COR-1 NS cell line can be expanded in culture without losing its ability to be differentiated into neurons, astrocytes, or oligodendrocytes (Conti et al., 2005; Pollard et al., 2006). The cells express DAGL $\alpha$ and DAGL $\beta$, as well as the $\mathrm{CB}_{1}$ and $\mathrm{CB}_{2}$ receptors, and importantly, like endogenous NS cells in the adult brain, DAGLdependent activation of $\mathrm{CB}_{1}$ and $\mathrm{CB}_{2}$ receptors is required for optimal proliferation (Goncalves et al., 2008). It follows that they are likely to be a useful model for initial studies aimed at determining whether eCB signaling is required for NS cell migration.
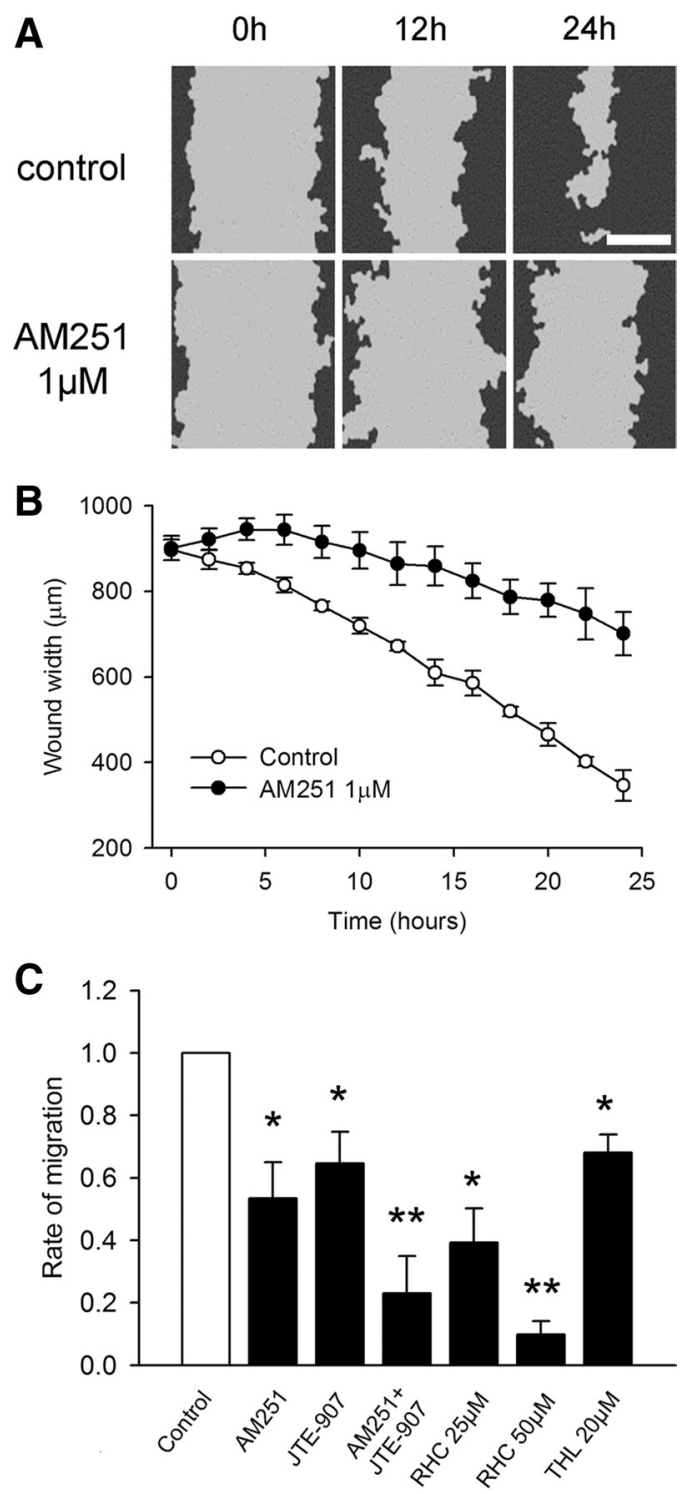

Figure 1. Endocannabinoid receptor activity is required for NS cell migration in culture. A confluent COR-1 cell monolayer was scratched, and various drugs inhibiting eCB signaling were added for an additional $24 \mathrm{~h}$ period of culture. Pictures of the wound were taken in the Incucyte every $2 \mathrm{~h}$ for $24 \mathrm{~h}$. $\boldsymbol{A}$, Representative pictures of the wound at several time points from control cells and cells treated with $1 \mu \mathrm{m} \mathrm{AM} 251, \mathrm{CCB}_{1}$ antagonist. $\boldsymbol{B}$, Representative curve showing the change in wound width over time in cells during the $24 \mathrm{~h} \mathrm{AM} 251$ treatment. $\boldsymbol{C}$, Inhibition of cannabinoid signaling significantly impairs migration. The rate of migration was measured by calculating the area under the curve when cells were treated with $1 \mu \mathrm{M} \mathrm{AM} 251,1 \mu \mathrm{M}$ JTE-907 ( $C B_{2}$ receptor antagonist), $1 \mu \mathrm{M}$ AM251 and JTE-907 together, RHC80267 (DAGLs inhibitor) at 25 and $50 \mu \mathrm{M}$, and THL (DAGLs inhibitor) at $20 \mu \mathrm{m}$. Graph shows mean $\pm \operatorname{SEM}(n=3)$; ${ }^{*} p<$ $0.05,{ }^{* *} p<0.001$. Scale bar, $500 \mu \mathrm{m}$.

Cell migration was assessed in full growth medium using live cell imaging in a "scratch wound" assay. This involves making a scratch wound in an established confluent cell monolayer; closure of the wound is driven primarily by cell migration from the edge of the scratch with the rate of migration calculated by measuring the change in wound width over time (EtienneManneville et al., 2001). When confluent monolayers of COR-1 cells are scratched, the wound typically fills in over a period of $\sim 24$ h (Fig. $1 A, B$ ). Importantly, we found no evidence of significant proliferation in these conditions during the time of the assay, and wound closure is not inhibited by the anti-proliferative drug mitomycin C (supplemental Fig. 4, 
available at www.jneurosci.org as supplemental material). In contrast, as shown in Figure 1, $A$ and $B$, wound closure was significantly inhibited by a selective $C_{1}$ receptor antagonist (AM251, $1 \mu \mathrm{M})$. Results pooled from three independent experiments show a $\sim 50 \%(p<0.05)$ reduction in wound closure rate in the presence of this drug (Fig. $1 C$ ). A similar decrease $(\sim 40 \%$, $p<0.05$ ) was observed with a selective $\mathrm{CB}_{2}$ antagonist (JTE-907, $1 \mu \mathrm{M}$ ) (Fig. 1C). Inhibition of both $\mathrm{CB}_{1}$ and $\mathrm{CB}_{2}$ receptors caused a more substantial decrease in migration $(\sim 80 \%, p<0.01)$ (Fig. $1 C)$. Because DAGL activity appears to sustain eCB tone in COR-1 and other NS cell lines (Goncalves et al., 2008), we investigated whether DAGL activity was also important for NS cell migration in culture. RHC80267 inhibits the activity of DAGL $\alpha$ and DAGL $\beta$ at 10-50 $\mu \mathrm{M}$ (Bisogno et al., 2003). At concentrations of 25 and $50 \mu \mathrm{M}, \mathrm{RHC} 80267$ substantially decreased ( $\sim 60 \%, p<0.05$ and $\sim 80 \%, p<0.01$, respectively) the rate of migration of COR-1 cells to a level similar to that seen with the combination of $\mathrm{CB}_{1}$ and $\mathrm{CB}_{2}$ antagonists (Fig. $1 C$ ). THL, another inhibitor of DAGL $\alpha$ and DAGL $\beta$ activity (Bisogno et al., 2003), also significantly decreased the rate of migration of COR-1 cells (Fig. 1C). Recent evidence suggests that, because the overlap in target profiles for serine hydrolases in the brain with RHC80267 and THL is limited to two enzymes other than the DAGLs that do not exhibit significant hydrolytic activity using 1stearoyl-2-AG as a substrate, any pharmacological effects seen with both drugs can be viewed as good evidence for a DAGL $\alpha / \beta$-dependent event (Hoover et al., 2008). Overall, these results suggest that a DAGLdriven eCB pathway is required for the migration of COR-1 cells.

\section{Activation of cannabinoid receptors increases stem cell migration in culture}

After demonstrating that blocking $\mathrm{CB}$ receptors decreased the migration of COR-1 cells in the wound assay, we wanted to investigate whether wound closure could be stimulated by $\mathrm{CB}_{1}$ and/or $\mathrm{CB}_{2}$ receptor agonists. As seen in Figure $2 \mathrm{~A}$, when COR-1 cells were treated with a selective $\mathrm{CB}_{1}$ agonist (ACEA, $0.75 \mu \mathrm{M}$ ), the rate of wound closure was greater than that of the control untreated culture (Fig. $2 A, B$ ). Overall, treatment with the $\mathrm{CB}_{1}$ receptor agonist increased the rate of closure by $\sim 50 \%(p<$ 0.05 ) (Fig. 2C). This effect was completely blocked by the selective $\mathrm{CB}_{1}$ antagonist (AM251, $1 \mu \mathrm{M}$ ) (Fig. 2C). Treatment with a selective $\mathrm{CB}_{2}$ agonist (JWH-133, $\left.1 \mu \mathrm{M}\right)$ also significantly $(p<$ 0.05 ) increased the rate of wound closure but by a more muted $25 \%$ (Fig. 2C). This increase was prevented when a selective $\mathrm{CB}_{2}$ antagonist was included in the medium (JTE-907, $1 \mu \mathrm{M}$ ) (Fig. $2 C$ ). Together, these results suggest that the $\mathrm{eCB}$ signaling system in a NS cell line can couple to and regulate a migratory response.

\section{Migrating neuroblasts express the main components of the eCB signaling system}

The above results suggest that, within the NS cell lineage, parental stem cells make and respond to 2-AG. We then wanted to determine whether migrating neuroblasts, and in particular those derived from stem cells that reside in the SVZ, retain expression of DAGL $\alpha$. Figure $3 A$ shows the RMS in a young mouse labeled with antibodies to PSA-NCAM, a well characterized marker for migrating neuroblasts. The majority of the cells in the RMS also clearly expressed DAGL $\alpha$ as demonstrated with antibodies validated to be specific for this enzyme (Yoshida et al., 2006; Gao et al., 2010) (Fig. 3B). Interestingly, at higher magnification, it can be seen that GFAP-positive astrocytes in the RMS do not express detectable levels of DAGL $\alpha$ (Fig. 3C). We also cultured primary mouse RMS neuroblasts on a laminin/poly-ornithine substrate
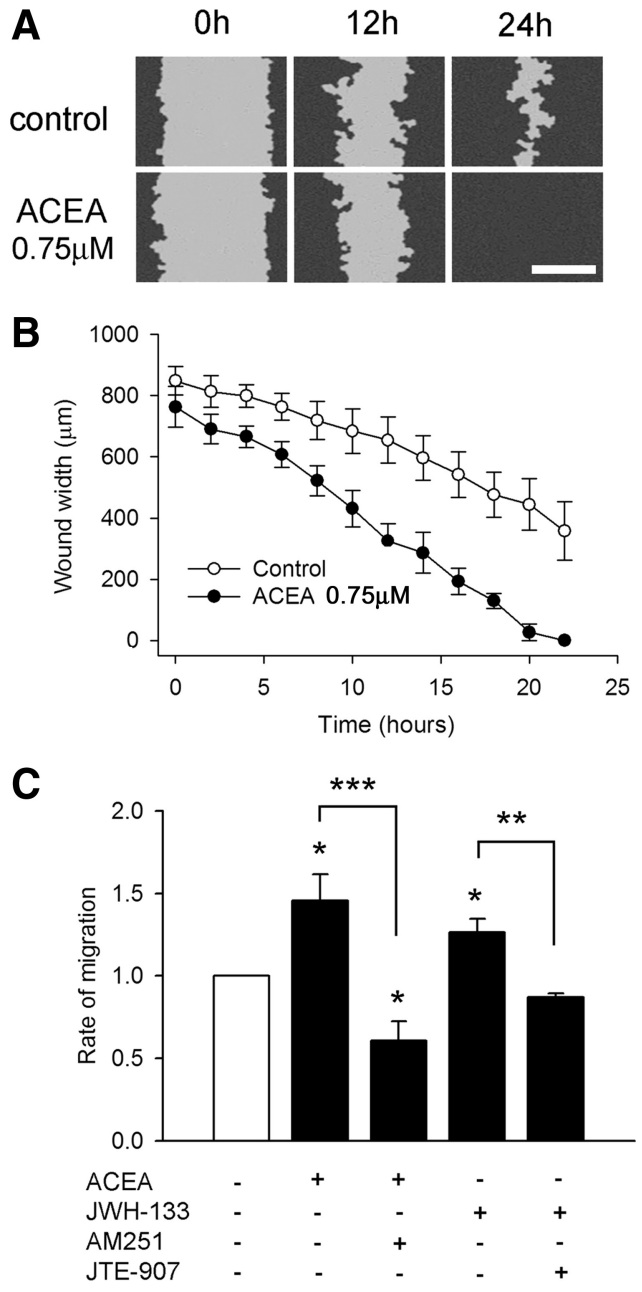

Figure 2. Activation of cannabinoid receptors increases NS cell migration. A confluent COR-1 cell monolayer was scratched to create a wound and treated with various drugs activating eCB signaling. The cells were imaged in the Incucyte every $2 \mathrm{~h}$ for $24 \mathrm{~h}$. $\boldsymbol{A}$, Representative pictures of the wound at several time points from control cells and cells treated with $0.75 \mu \mathrm{m} \mathrm{ACEA,} \mathrm{a} \mathrm{CB}$ agonist. $\boldsymbol{B}$, Representative curve showing the change in wound width over time during the $24 \mathrm{~h}$ ACEA treatment. In $\boldsymbol{C}$, the rate of migration was measured by calculating the area under the curve after cells were treated with $0.75 \mu \mathrm{m} A C E A$, as well as in the presence of the $\mathrm{CB}_{1}$ antagonist AM251 at $1 \mu \mathrm{m}$ or JWH-133 at $1 \mu \mathrm{M}\left(\mathrm{CB}_{2}\right.$ agonist) as well as in the presence of $1 \mu \mathrm{m}$ JTE-907 $\left(\mathrm{CB}_{2}\right.$ antagonist). Graph shows mean $\pm \mathrm{SEM}(n=3) ;{ }^{*} p<0.05,{ }^{* *} p<0.01,{ }^{* * *} p<0.001$. Scale bar, $500 \mu \mathrm{m}$.

for 24-72 $\mathrm{h}$ and then stained the cultures for the various components of the eCB system. At low magnification, all neuroblasts (labeled with DCX or PSA-NCAM) are positive for DAGL $\alpha$, the $\mathrm{CB}_{1}$ and $\mathrm{CB}_{2}$ receptors, and MAGL (supplemental Fig. 5, available at www.jneurosci.org as supplemental material). Highermagnification images show that DAGL $\alpha$ is highly expressed in the neuroblast, all the way to the tip of the filopodia in the terminal growth cone-like structure (Fig. $3 D, F$ ). The $\mathrm{CB}_{1}$ receptor shows a punctate distribution throughout the cell (Fig. 3E,F) partially overlapping with DAGL $\alpha$ (Fig. $3 F$ ). Thus, migrating neuroblasts clearly retain the machinery to make $2-\mathrm{AG}$ and to respond to it.

\section{eCB tone is important for the migration of neuroblasts out of RMS explants}

To investigate the role of the eCB system in neuroblast migration, freshly dissected RMS tissue explants from the early postnatal brain were embedded in a Matrigel three-dimensional matrix, a 
technique which has been described previously to recreate the chain migration of neuroblasts known to occur in vivo (Wichterle et al., 1997) (Fig. 4A). Staining of RMS explants embedded in Matrigel confirmed that virtually all cells migrating out of the explant were positive for migrating neuroblast markers, such as PSANCAM and DCX (Lois et al., 1996; Brown et al., 2003) (data not shown). We then treated the RMS explants with different cannabinoid receptor antagonists and DAGL inhibitors and measured the migration of neuroblasts out of the explant. Explants were initially treated with the $\mathrm{CB}_{1}$ antagonist $\mathrm{AM} 251$ at $0.5 \mu \mathrm{M}$ and fixed after $6 \mathrm{~h}$ (Fig. $4 \mathrm{~B}$ ). We chose as short an assay period as possible because we were concerned that endogenous factors that might drive eCB signaling could be lost with time. The migration distance was significantly $(p<0.05)$ reduced by $30 \%$ after treatment with AM251 (Fig. 4D). Similarly, treatment with the $\mathrm{CB}_{2}$ antagonist JTE-907 at 0.5 $\mu \mathrm{M}$ also caused a significant $(p<0.05)$ $40 \%$ decrease in migration after $6 \mathrm{~h}$ (Fig. $4 C, D)$. Simultaneous addition of both antagonists did not further increase the effect obtained by each single antagonist on its own. Moreover, no less than three different DAGL inhibitors, RHC80267 (50 $\mu \mathrm{M})$, THL (20 $\mu \mathrm{M})$, and OMDM188 $(0.25 \mu \mathrm{M})$, significantly $(p<0.05)$ reduced the migration of neuroblasts to an extent similar to treatment with the $\mathrm{CB}_{1}$ and $\mathrm{CB}_{2}$ antagonists and did so at concentrations that are required to block DAGL $\alpha$ and DAGL $\beta$ activity in intact cells (Bisogno et al., 2003; Ortar et al., 2008) (Fig. 4D). To confirm that the effect observed was not attributable to an effect on cell proliferation, explants were stained for nuclear cell proliferation antigen Ki67 (Kee et al., 2002). When treated with the drugs mentioned above, no changes in the number of Ki67-positive cells were observed, confirming that the effects seen were attributable to changes in migration and not proliferation (data not shown). These results indicate that eCB signaling, and more specifically a $\mathrm{DAGL} / \mathrm{CB}_{1} / \mathrm{CB}_{2}$ pathway, is required for $\mathrm{SVZ}$-derived neuroblast migration.

\section{Activation of cannabinoid receptors increases the migration of neuroblasts out of RMS explants}

After showing that an endogenous eCB tone is important for the migration of SVZ-derived neuroblasts in culture, we wanted to investigate whether activation of the cannabinoid receptors could stimulate migration. After dissection, explants were treated with $0.5 \mu \mathrm{M} \mathrm{CB} \mathrm{C}_{1}$ agonist ACEA for $24 \mathrm{~h}$. The $\mathrm{CB}_{1}$ agonist had a clear and pronounced effect on cell migration out of the explants (Fig. $5 A, B)$, with cells on average migrating $65 \%$ farther compared with control cultures $(p<0.05)$ (Fig. $5 C$ ). This increase in migrated distance was blocked by the $\mathrm{CB}_{1}$ antagonist $\mathrm{AM} 251$, confirming this was a $\mathrm{CB}_{1}$-mediated effect (Fig. 5C). Likewise, treatment with the $\mathrm{CB}_{2}$ agonist JWH-133 $(0.5 \mu \mathrm{M})$ also led to a significant $(p<0.05) \sim 50 \%$ increase in migrated distance, with this effect blocked by the $\mathrm{CB}_{2}$ antagonist (JTE-907, $1 \mu \mathrm{M}$ ) (Fig. $5 C)$. Treatment with both agonists at the same time did not fur- ther potentiate the effect of each agonists added separately (Fig. $5 C$ ). Interestingly, although the $\mathrm{CB}_{1}$ and $\mathrm{CB}_{2}$ antagonists readily blocked the migratory activity of the respective agonists over a $24 \mathrm{~h}$ period, they did not reduce migration to below the level seen in the control cultures (Fig. 5C). This suggests that the eCB tone revealed by drug inhibition over the initial $6 \mathrm{~h}$ after explant embedding is lost over a longer period of culture, perhaps as a result of the washout of factors driving the pathway. We also found that treatment with ACEA significantly increased the number of cells present at any given distance, and this effect was blocked by the $\mathrm{CB}_{1}$ antagonist AM251 (data not shown). Similar effects were seen when explants were treated with the $\mathrm{CB}_{2}$ agonist JWH-133 (data not shown). Therefore, stimulation of cannabinoid receptors increased not only the extent of migration but also the number of cells migrating out of the explants.

Another way to enhance cannabinoid signaling is to inhibit the hydrolysis of 2-AG, one of the main endocannabinoids in the brain. Mice treated with the selective MAGL inhibitor JZL-184 had an eightfold increase in 2-AG levels but also displayed behaviors that are normally seen with cannabinoid receptor stimulation (Long et al., 2009). Treatment with JZL-184 (0.5 $\mu \mathrm{M})$ led to a significant $30 \%$ increase in migration out of the explants (Fig. $5 D)$. Inhibition of this effect required the simultaneous block of $\mathrm{CB}_{1}$ or $\mathrm{CB}_{2}$ receptors, suggesting that both receptors contribute to the response (Fig. 5D). In addition, as expected, the response was not seen in cultures treated with a DAGL inhibitor (RHC80267) (Fig. 5D), suggesting that 2-AG synthesis is required for the response. Overall, these data support the hypothesis that $2-\mathrm{AG}$ is the $\mathrm{eCB}$ responsible for the migratory response and that this response can be driven by activation of the $\mathrm{CB}_{1}$ or $\mathrm{CB}_{2}$ receptors on the migratory neuroblasts. 


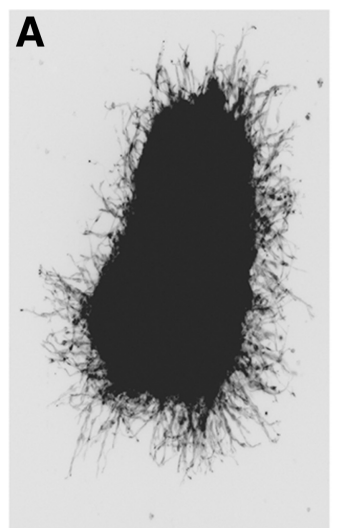

control

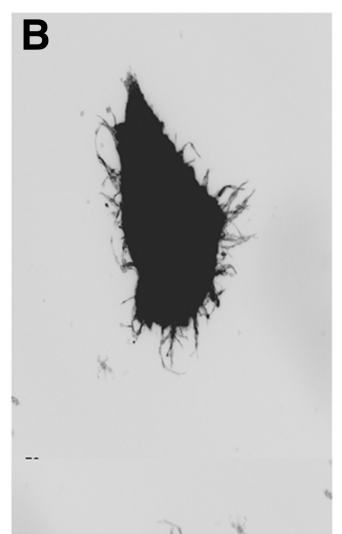

AM251

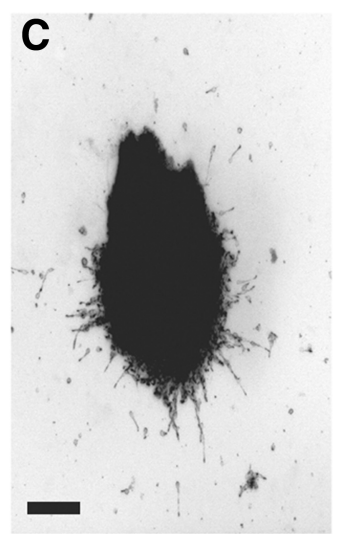

JTE-907

D

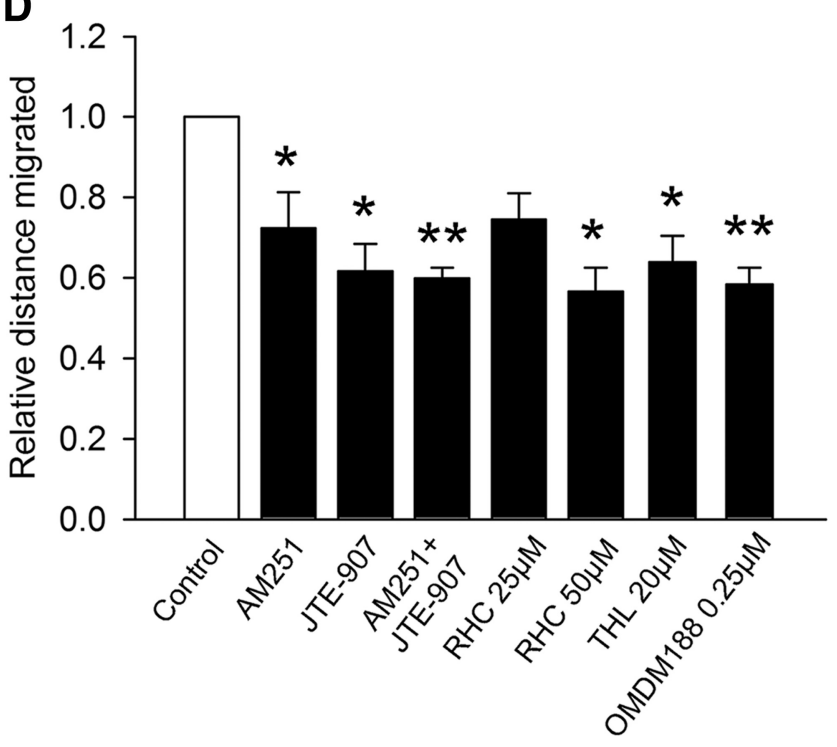

Figure 4. Endocannabinoid tone is important for RMS neuroblast migration. Mouse RMS explants were embedded in Matrigel and left to migrate for $6 \mathrm{~h}$ before fixation. Representative pictures of explants treated with vehicle $(A), 0.5 \mu \mathrm{M}$ AM251 (CB antagonist) ( $\boldsymbol{B}$ ), and $0.5 \mu \mathrm{M} \mathrm{JTE}-907$ ( $\left(\mathrm{CB}_{2}\right.$ antagonist) (C). D, Quantification of the distance migrated by the cells from the edge of explant. Treatment with AM251, JTE-907, and the DAGL inhibitors RHC80267, THL, and OMDM188 significantly decreases migration out of the explant. Graph shows mean $\pm \operatorname{SEM}(n=4) ;{ }^{*} p<0.05,{ }^{* *} p<0.01$. Scale bar, $100 \mu \mathrm{m}$.

\section{eCB signaling regulates nucleokinesis}

Neuronal migration is generally characterized by several discrete steps, one of the most crucial being nucleokinesis, the saltatory movement of the nucleus into the leading process (Schaar et al., 2005; Marin et al., 2010). We used time-lapse imaging to better examine nucleokinesis in the neuroblasts migrating out of RMS explants. In control medium, the nucleus of migrating neuroblasts displayed periods in which it was essentially immobile coupled with periods of greater movement, generally covering distances up to $10-15 \mu \mathrm{m}$. A representative trace showing the movement of a single nucleus over an $\sim 4 \mathrm{~h}$ period in control conditions is shown in Figure 6 A. For quantitative purposes, we considered only single nuclear movements longer than $5 \mu \mathrm{m}$. Following this criterion, on average, control cells display $\sim 1.5$ saltatory nuclear movements per hour (Fig. 6C). Interestingly, nucleokinesis was dramatically impaired when cells were treated with a $\mathrm{CB}_{1}$ antagonist (AM251, $1 \mu \mathrm{M}$ ) with a highly significant $(p<0.001)$ approximately threefold reduction of nuclear movements per hour relative to the control (Fig. 6A,C). In contrast, treatment with a $\mathrm{CB}_{1}$ agonist (ACEA, $0.5 \mu \mathrm{M}$ ) led to a highly significant $(p<0.001)$ more than twofold increase in the num- ber of saltatory movements (Fig. $6 B, C$ ). Targeting the $\mathrm{CB}_{2}$ receptor led to similar, although more muted, responses (Fig. $6 C)$. In addition, JZL-184, a selective inhibitor of MAGL (Long et al., 2009), the enzyme responsible for most of the hydrolysis of 2-AG in the brain (Blankman et al., 2007), also significantly increased the number of saltatory movements per hour (Fig. 6C). On the contrary, inhibition of eCB signaling increased nuclear oscillations over very small distances (Fig. 6A and data not shown), ultimately affecting the neuroblast ability to migrate out of the explants. Representative movies of migrating cells can be viewed at http:// www.kcl.ac.uk/schools/biohealth/research/ wolfson/supplementarymaterial.html.

Together, these data suggest that $\mathrm{eCB}$ signaling can play an important role in the regulation of nucleokinesis in migrating neuroblasts.

\section{The cannabinoid system regulates process length and branching of migrating neuroblasts}

Another discrete step in the migratory process is the extension of a single leading process that can affect both the rate and direction of movement. This event shares many features with axonal growth, and, in this context, eCB signaling promotes axonal outgrowth (Williams et al., 2003). We measured the average length of the leading process of the migratory neuroblasts (see Materials and Methods) in control conditions and in the presence of $\mathrm{CB}_{1}$ and $\mathrm{CB}_{2}$ receptor agonists or antagonists. Representative images of the morphology of the phalloidin-stained cells can be seen in Figure $7 A-C$. As with many of the responses described above, the most dramatic effects were observed with drugs that target the $\mathrm{CB}_{1}$ receptor. Indeed, the $\mathrm{CB}_{1}$ agonist increases process length, whereas the $C_{1}$ antagonist decreases it. These effects were highly significant relative to the controls $(p<0.001)$, and remarkably there was a sixfold difference between the average process length measured between agonist- and antagonisttreated cultures (Fig. $7 D$ ). The $\mathrm{CB}_{2}$ agonist had a similar effect to the $\mathrm{CB}_{1}$ agonist, but the $\mathrm{CB}_{2}$ antagonist did not significantly affect process length (Fig. $7 D$ ). Again, effects similar to the $\mathrm{CB}_{1} / \mathrm{CB}_{2}$ agonists were elicited by the selective MAGL inhibitor, implicating 2-AG in the physiological pathway controlling process extension.

Migrating neurons have been shown to change direction through repeated rounds of process extension and retraction, forming new protrusions either by extending a new process from the side of an existing process or directly from the cell soma (Ward et al., 2005a). Branching defects in migrating neurons have been reported previously to impact the rate of migration (Gupta et al., 2003; Koizumi et al., 2006). Therefore, we wanted to investigate whether the eCB system also plays a role in process formation and quantified the number of branching points per 


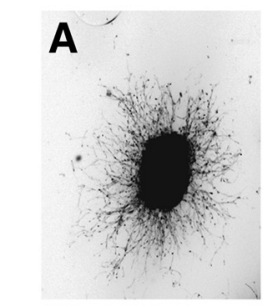

control

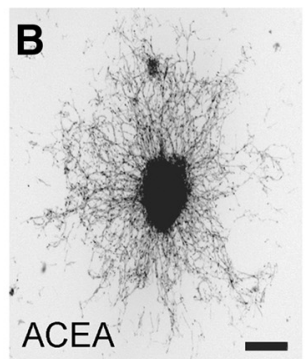

C
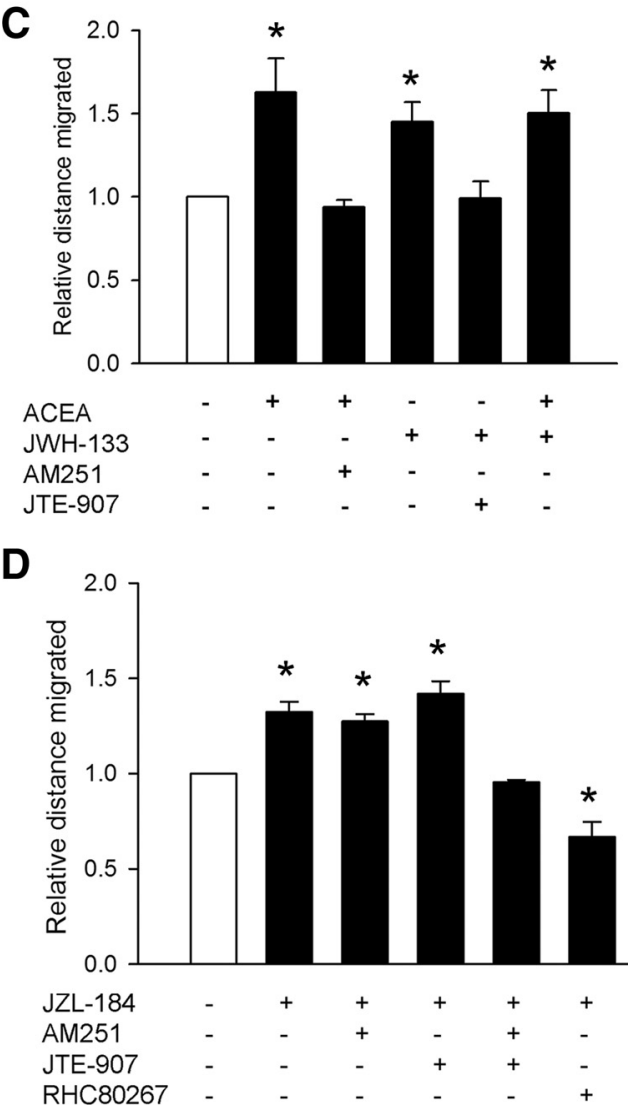

Figure 5. Activation of cannabinoid receptors increases migration out of RMS explants. RMS explants were embedded in Matrigel and left to migrate for $24 \mathrm{~h}$ before fixation. Representative pictures of explants treated with vehicle $(\boldsymbol{A})$ and $0.5 \mu \mathrm{M} A C E A\left(C_{1}\right.$ agonist) $(\boldsymbol{B})$. C, Quantification of the distance migrated by the cells from the edge of explant. ACEA significantly increases the distance migrated by cells, and this effect is blocked by the $\mathrm{CB}_{1}$ antagonist $\mathrm{AM} 251$. Similarly, explants treated with JWH-133 also migrate farther than control, and this effect is blocked by the $\mathrm{CB}_{2}$ antagonist JTE-907. D, Quantification of the distance migrated of cells out of the explant. JZL-184, an MAGL inhibitor, significantly increases migration, and this effect is only blocked when both CB receptors are inhibited or when DAGL is inhibited. Graph shows mean \pm SEM $(n=4) ;{ }^{*} p<0.05$. Scale bar, $200 \mu \mathrm{m}$.

neuroblast per frame. Treatment with cannabinoid receptor agonists, or the selective MAGL inhibitor, had no effect on the number of branching points (Fig. $7 E$ ), and in these conditions neuroblasts tended to display a highly polarized morphology characterized by a single long protrusion (Fig. $7 B$ ). However, inhibiting either $\mathrm{CB}_{1}$ or $\mathrm{CB}_{2}$ receptors caused a dramatic threefold to fivefold increase in branching compared with control (Fig. $7 C, E)$. This effect was primarily attributable to enhanced secondary branches extending from the main protrusion. Overall, these data suggest that the $\mathrm{eCB}$ system contributes to maintain a polarized morphology in the migrating neuroblasts by promoting the extension of a single major leading process.
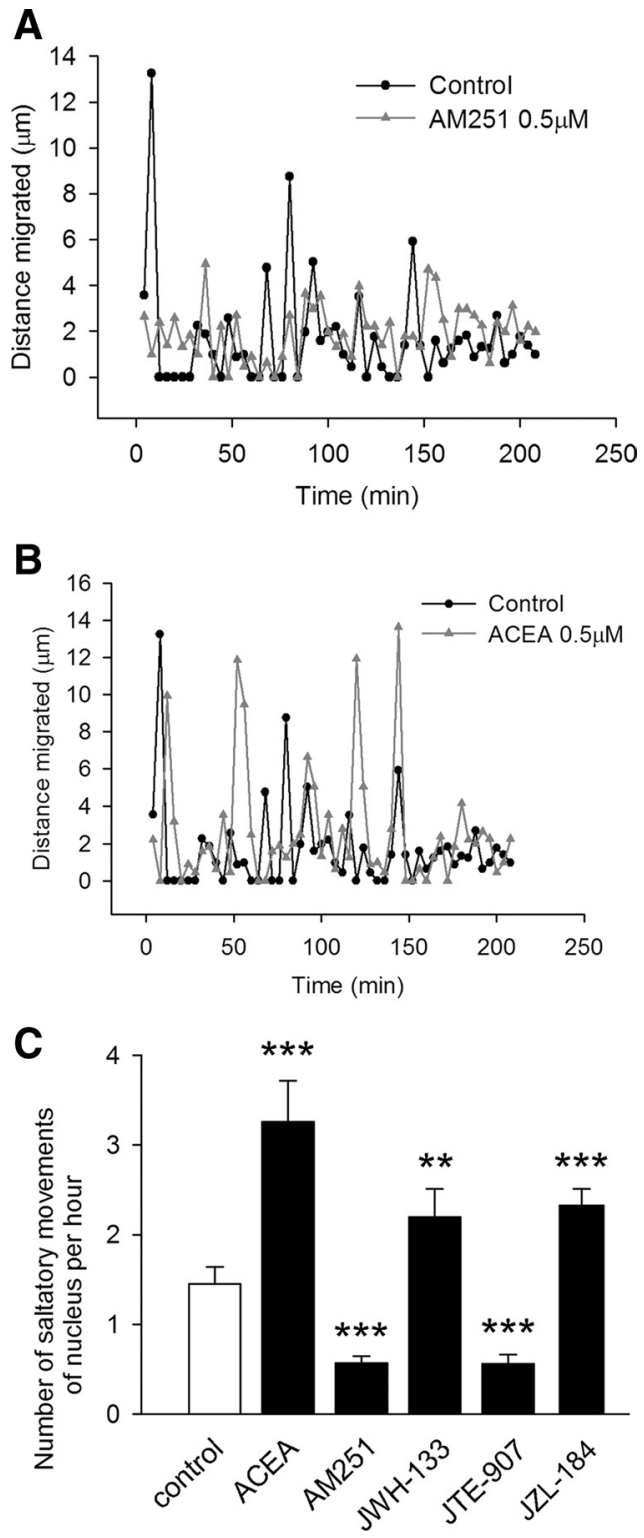

Figure 6. The eCB system regulates neuroblast motility. RMS explants were embedded in Matrigel and treated with various drugs targeting the eCB system. The explants were imaged in the Nikon Biostation for $24 \mathrm{~h}$. $A$, Representative nuclear movement distances between frames (4 min apart) of a control (black) and AM251-treated cell (gray). $\boldsymbol{B}$, Representative nuclear movement distances of a control (black) and ACEA-treated cell (gray). C, Number of saltatory nuclear movements (displacement of over $5 \mu \mathrm{m}$ ) per hour in migrating neuroblasts. Inhibition of cannabinoid signaling significantly decreases the number of saltatory nuclear movements, whereas activation of cannabinoid signaling increases the number of nucleokinesis events. Graph shows mean \pm SEM $\left(n=40\right.$ cells at least per condition; $\left.{ }^{* *} p<0.01,{ }^{* * *} p<0.001\right)$.

The cannabinoid system regulates process length and branching of migrating neuroblasts in the brain

Our experiments with RMS explant cultures strongly support a role for the endocannabinoid system in neuroblast migration. Therefore, we wanted to examine whether the eCB system might have a function in neuroblast migration in vivo. To do so, we labeled RMS migrating neuroblasts by postnatal electroporation of a GFPexpressing plasmid in the SVZ (Boutin et al., 2008) (Fig. 8A). The GFP-labeled cells found in the RMS (Fig. 8B) are SVZ-derived migrating neuroblasts, which are positive for PSA-NCAM (data not shown). Fourteen days after electroporation, animals were treated with one of four cannabinoid receptor inhibitors: two independent 

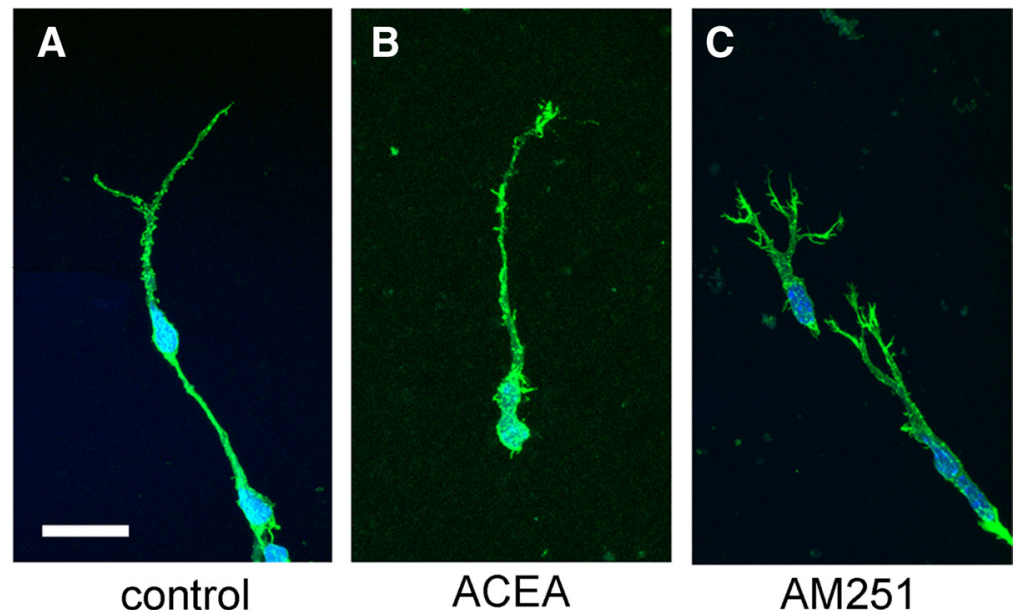

control

ACEA

AM251

D

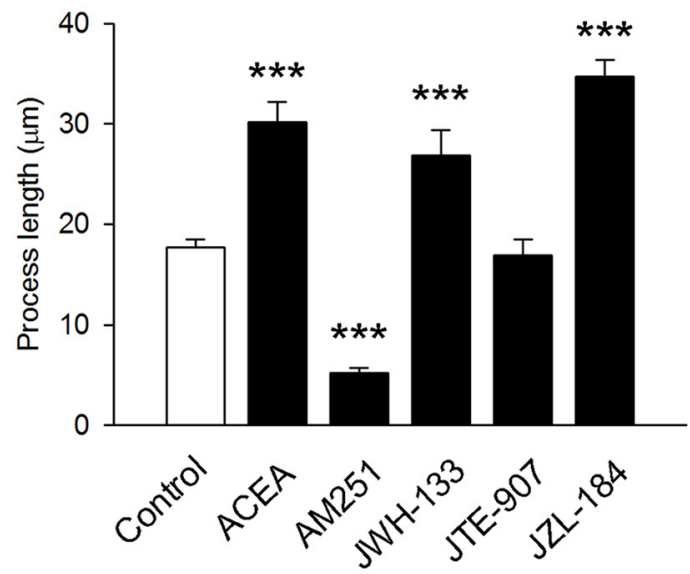

$\mathbf{E}$

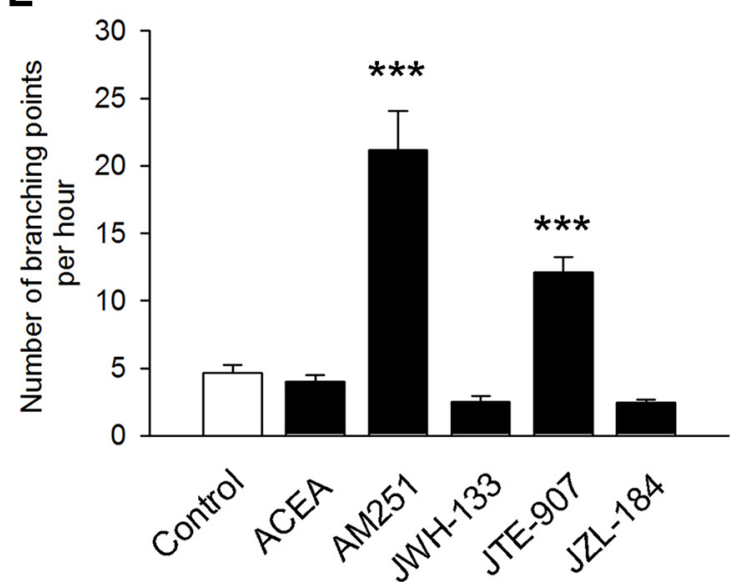

Figure 7. The eCB system regulates process length and branching of cultured neuroblasts. RMS explants were embedded in Matrigel, treated with various drugs targeting the e(B system, and imaged in the Nikon Biostation for $24 \mathrm{~h}$. Representative pictures of migrating neuroblasts treated with vehicle $(\boldsymbol{A})$, ACEA at $0.5 \mu \mathrm{M}(\boldsymbol{B})$, or AM251 at $0.5 \mu \mathrm{M}(\boldsymbol{C})$ and stained with fluorescent phalloidin. $\boldsymbol{D}$, Average leading process length was measured for cells treated with each drug. $\boldsymbol{E}$, Number of branching points per hour was counted for each drug treatment. The eCB system significantly regulates process length and branching in migrating neuroblasts in culture. Graph shows mean $\pm \operatorname{SEM}(n=4$, with at least 30 cells measured for each condition for each experiment). ${ }^{* * *} p<0.001$. Scale bar, $20 \mu \mathrm{m}$.

$\mathrm{CB}_{1}$ antagonists, AM251 and LY320135, and two independent $\mathrm{CB}_{2}$ antagonists, JTE-907 and AM630 (6-iodo-2-methyl-1-[2-(4-morpholinyl)ethyl]- $1 \mathrm{H}$-indol-3-yl), at $5 \mathrm{mg} / \mathrm{kg}$ via intraperitoneal injections (Goncalves et al., 2008). Animals were killed $24 \mathrm{~h}$ later, and their brains were sliced and subsequently stained for GFP to study the morphology of migratory neuroblasts. In control animals, neuroblasts within the RMS generally extend a single process with an average length of $45 \mu \mathrm{m}$ (Fig. $8 C, F, I$ ); this is usually oriented toward the olfactory bulb. In the animals treated with $\mathrm{CB}_{1}$ or $\mathrm{CB}_{2}$ antagonists, average process length was significantly shorter than in vehicle-treated animals (Fig. 8J,K). Indeed, treatment with cannabinoid antagonists caused a $40-50 \%$ reduction $(p<0.01)$ in the leading process length of neuroblasts sampled throughout the RMS (Fig. $8 \mathrm{~L}$ ), suggesting that $\mathrm{eCB}$ signaling operates along the entire stream. In vehicle-treated animals, $80 \%$ of migrating neuroblasts had one main protrusion, with occasional branching at the tip of the growth cone (Fig. $8 C, F, I)$. Treatment with $\mathrm{CB}_{1}$ and $\mathrm{CB}_{2}$ antagonists caused a significant increase $(p<0.05)$ in the percentage of cells displaying secondary branching (Fig. $8 M$ ), defined as a protrusion from their leading process $>1$ somal length removed from the tip of the growth cone, to differentiate it from a branched growth cone (Koizumi et al., 2006), or additional protrusions extending directly from the soma. Indeed, some cells displayed long branches from the cell body (Fig. 8D,E), whereas others exhibited short branches forming all along the leading process (Fig. 8G,H). There were no obvious differences in the phenotype of cells treated with $\mathrm{CB}_{1}$ relative to $\mathrm{CB}_{2}$ antagonists. Importantly, these effects are similar to those observed in cultured neuroblasts and strongly point to a crucial role for the $\mathrm{eCB}$ system in the regulation of neuroblast migration in the postnatal RMS.

\section{Discussion}

The directed migration of SVZ-derived neuroblasts out of the RMS could offer the possibility of neuronal repair within the damaged brain. Indeed, focal ischemia triggers SVZ cell proliferation, leading to neuroblast migration toward the striatum, which has been observed for $>1$ year after the initial injury (Arvidsson et al., 2002; Kokaia et al., 2006; Zhang et al., 2004, 2007). A full understanding of the pathways regulating migration might provide new therapeutic opportunities. In the present study, we have investigated the role of eCB signaling in neuroblast migration for several reasons. First, SVZderived neuroblasts are the progeny of NS cells that express the main components of the eCB signaling system, and whereas a role in the proliferation of these cells is well established, a role in their migration had remained unexplored. Second, eCBs are upregulated in the injured brain, and they can regulate the migration of many other cell types, suggesting that they might be candidates for regulating 
neuroblast migration in the injured brain. Finally, several of the factors that play a role in neuroblast migration in the RMS are capable of activating $\mathrm{eCB}$ signaling (discussed below).

Initially, we tested a role for $\mathrm{eCB}$ signaling in migration using the COR-1 NS cell line because these cells express DAGL $\alpha / \beta$ and both cannabinoid receptors, and like NS cells in the adult hippocampus and SVZ, they require eCB signaling for proliferation (Goncalves et al., 2008). Using a scratch wound assay, our results show that, when the cells are maintained in full growth media, both $\mathrm{CB}_{1}$ and $\mathrm{CB}_{2}$ antagonists can substantially inhibit their migration (by up to $80 \%$ ), a response also seen with two distinct DAGL inhibitors. Under similar highdensity culture conditions, these drugs have no effect on proliferation or survival, so these are not confounding issues (data not shown). A recent microarray-based analysis shows that the $\mathrm{CB}_{1}$ and $\mathrm{CB}_{2}$ receptors regulate the expression of a common set of transcripts in COR-1 cells (Doherty laboratory, unpublished observation), including some that encode for molecules known to regulate migration, e.g., the Smurf1 E3 ubiquitin-protein ligase (Huang, 2010), the small GTPase Cdc42 (Jaffe et al., 2005), or myosin1C (Diefenbach et al., 2002). Thus, both cannabinoid receptors appear to couple to common second-messenger cascades. Indeed, the increased speed of wound closure obtained with selective cannabinoid agonists further supports the coupling of both $\mathrm{CB}$ receptors to a migratory response, as reported in hematopoietic cells (Patinkin et al., 2008) and vascular endothelial cells (Blázquez et al., 2003).

The above eCB signaling components continue to be expressed in SVZ-derived neuroblasts, in which they appear also to be important for polarized migration. Indeed, $\mathrm{CB}_{1} / \mathrm{CB}_{2}$ antagonists and no less than three independent DAGL inhibitors inhibit migration of neuroblasts out of RMS explants. This effect was seen during the initial $6 \mathrm{~h}$ period of culture but not at $24 \mathrm{~h}$. This suggests that factors driving an $\mathrm{eCB}$ tone in the explants might be washed out over longer periods of time (note that the culture media for the explants was not supplemented with exogenous growth factors). Nonetheless, this provides a good control to demonstrate that the drugs do not have any general nonspecific effects on migration, which would be expected to be exacerbated over time. Importantly, the cells retain the ability to migrate in response to eCB signaling as $\mathrm{CB}_{1}$ or $\mathrm{CB}_{2}$ receptor agonists, and a drug that prevents $2-\mathrm{AG}$ breakdown stimulated migration from the explants over a $24 \mathrm{~h}$ period.

The migration of many cells, including neuroblasts, is characterized by several typical features. Migratory cells are generally highly polarized with a single leading process. Cellular movement relies on efficient nucleokinesis, the highly regulated translocation of the nucleus along the leading process (Marin et al., 2010). Our live cell imaging analysis has uncovered a substantial role for the eCB pathway in neuroblast migration. For example, we found a sixfold increase in both the number of nuclear saltatory movements and the mean length of the leading process when cells are subjected to eCB signaling activation compared with cells treated with selective $\mathrm{CB}$ antagonists, which also caused a striking fivefold increase in the number of branch points. Overall, these results strongly support a role for eCBs in ensuring an efficient polarized migration. The exact molecular mechanism underlying this function, which is likely to involve modulation of the actin and microtubule cytoskeleton as well as localization of polarity regulators, remains to be clarified.

On the basis of our in vitro results, we asked whether an $\mathrm{eCB}$ tone is directly affecting neuroblast migration within the RMS in the living animal. To this end, we fluorescently labeled SVZderived neuroblasts by in vivo electroporation and allowed them to migrate along the RMS for several days. We then treated the animals for $24 \mathrm{~h}$ with selective $\mathrm{CB}$ antagonists and subsequently examined neuroblast morphology within the RMS. Remarkably, the effects of $\mathrm{CB}_{1}$ and $\mathrm{CB}_{2}$ antagonists on the morphology of neuroblasts within the RMS were very similar to the effects observed on cultured neuroblasts. In this context, inhibiting eCB signaling resulted in a 50\% decrease in the length of the leading process and a twofold increase in the percentage of cells with secondary branching, both of which have been described to dis- 
rupt normal migration (Gupta et al., 2003; Kappeler et al., 2006; Nasrallah et al., 2006). Interestingly, deletion of DCX from neuroblasts caused a similar decrease in primary process length and increase in secondary branching, and these were associated with defects in nuclear translocation and a decreased rate of migration (Koizumi et al., 2006). It was suggested that branching defects could lead to nuclear translocation defects and that these two events could be temporally related. The changes caused by cannabinoid antagonists on process length and branching observed both in ex vivo cultures and in vivo could be therefore responsible for the impaired nuclear translocation and, as a consequence, the decreased rate of migration.

2-AG is one of two well-established eCBs, the other being anandamide (Devane et al., 1992). Our results suggest that 2-AG drives eCB signaling in migratory neuroblasts. In this context, migrating neuroblasts selectively express DAGL $\alpha$ within their leading processes, and whereas three drugs that inhibit DAGLdependent 2-AG synthesis (RHC80267, THL, and OMDM188) reduced neuroblast migration out of RMS explants, a drug that selectively prevents 2-AG hydrolysis (JZL-184) increased it. Indeed, the effects of the selective MAGL inhibitor on neuroblast morphology were indistinguishable from those elicited by a number of $\mathrm{CB}_{1} / \mathrm{CB}_{2}$ agonists and the opposite of those seen with the DAGL inhibitors and $\mathrm{CB}_{1} / \mathrm{CB}_{2}$ antagonists. These results therefore suggest that 2-AG plays an important role in the regulation of neuroblast migration. The possibility of off-target effects affecting the interpretation of our results is extremely unlikely because results with any single drug (e.g., AM251) are internally consistent with the results obtained with numerous agents that we use to target the synthesis, action, and termination of the action of $2-A G$ at $\mathrm{CB}_{1} / \mathrm{CB}_{2}$ receptors and generally supported by the use of a similar drug from a different chemical class.

DAGL activity can in principle be activated by any receptor that stimulates the production of DAG, e.g., the FGF receptor (Williams et al., 2003), or any agent that increases intracellular calcium (Bisogno et al., 2003). Therefore, the eCB pathway could be integrating signals from several players. BDNF, which increases neuronal sensitivity to eCBs by increasing the level of $\mathrm{CB}_{1}$ transcripts (Maison et al., 2009), can also regulate the migration of neuroblasts through TrkB activation (Chiaramello et al., 2007). In addition, TrkB receptor transactivation was shown to mediate eCB-induced chemotaxis of cholecystokinin-expressing interneurons (Berghuis et al., 2005). Finally, NCAM function is required for neuroblast migration in the RMS (Tomasiewicz et al., 1993), and this is one of a number of CAMs that promotes neurite outgrowth by activating eCB signaling (Williams et al., 2003). Future studies will address which, if any, of the above actually activate eCB signaling in SVZ-derived neuroblasts.

Methods for enhancing neuroblast migration to sites of injury could be developed as a way of promoting brain repair. There is evidence that eCBs can direct the migration of immune system cells (Jordà et al., 2002; Lunn et al., 2006), and in the CNS, eCBs can be released by activated microglia and damaged neurons at sites of injury (Witting et al., 2006; Mechoulam et al., 2007). Thus, eCBs might attract neuroblasts to injury sites in the CNS; however, we think this is unlikely to attract cells from the RMS because 2-AG has a very short half-life and might not be expected to signal over considerable distances (Rouzer et al., 2002). Interestingly, NCAMs ability to promote neurite outgrowth is inhibited by removal of polysialic acid (Doherty et al., 1990), and a similar removal of polysialic acid from NCAM on migratory neuroblasts triggers their dispersion away from the RMS into the CNS, including the cortex and striatum (Battista et al., 2010). It follows that disrupting migration within the RMS with $\mathrm{CB}_{1}$ and/or $\mathrm{CB}_{2}$ antagonists might encourage the neuroblasts to leave their normal pathway and go to damaged areas of the brain.

In summary, we propose a new role for the $\mathrm{eCB}$ system in the regulation of neuroblast migration in the RMS in the postnatal brain. The key signaling molecules are the DAGLs, which drive an eCB tone via activation of both $\mathrm{CB}_{1}$ and $\mathrm{CB}_{2}$ receptors. Future studies will address the nature of the molecules that activate DAGL, as well as the signaling pathways that operate downstream from the $\mathrm{CB}_{1} / \mathrm{CB}_{2}$ receptors to regulate the cytoskeleton.

\section{References}

Aguado T, Monory K, Palazuelos J, Stella N, Cravatt B, Lutz B, Marsicano G, Kokaia Z, Guzmán M, Galve-Roperh I (2005) The endocannabinoid system drives neural progenitor proliferation. FASEB J 19:1704-1706.

Alvarez-Buylla A, Herrera DG, Wichterle H (2000) The subventricular zone: source of neuronal precursors for brain repair. Prog Brain Res 127:1-11.

Anton ES, Ghashghaei HT, Weber JL, McCann C, Fischer TM, Cheung ID, Gassmann M, Messing A, Klein R, Schwab MH, Lloyd KC, Lai C (2004) Receptor tyrosine kinase ErbB4 modulates neuroblast migration and placement in the adult forebrain. Nat Neurosci 7:1319-1328.

Arvidsson A, Collin T, Kirik D, Kokaia Z, Lindvall O (2002) Neuronal replacement from endogenous precursors in the adult brain after stroke. Nat Med 8:963-970.

Battista D, Rutishauser U (2010) Removal of polysialic acid triggers dispersion of subventricularly derived neuroblasts into surrounding CNS tissues. J Neurosci 30:3995-4003.

Berghuis P, Dobszay MB, Wang X, Spano S, Ledda F, Sousa KM, Schulte G, Ernfors P, Mackie K, Paratcha G, Hurd YL, Harkany T (2005) Endocannabinoids regulate interneuron migration and morphogenesis by transactivating the TrkB receptor. Proc Natl Acad Sci U S A 102:19115-19120.

Bisogno T, Howell F, Williams G, Minassi A, Cascio MG, Ligresti A, Matias I, Schiano-Moriello A, Paul P, Williams EJ, Gangadharan U, Hobbs C, Di Marzo V, Doherty P (2003) Cloning of the first sn1-DAG lipases points to the spatial and temporal regulation of endocannabinoid signaling in the brain. J Cell Biol 163:463-468.

Blankman JL, Simon GM, Cravatt BF (2007) A comprehensive profile of brain enzymes that hydrolyze the endocannabinoid 2-arachidonoylglycerol. Chem Biol 14:1347-1356.

Blázquez C, Casanova ML, Planas A, Gómez Del Pulgar T, Villanueva C, Fernández-Aceñero MJ, Aragonés J, Huffman JW, Jorcano JL, Guzmán M (2003) Inhibition of tumor angiogenesis by cannabinoids. FASEB J 17:529-531.

Boutin C, Diestel S, Desoeuvre A, Tiveron MC, Cremer H (2008) Efficient in vivo electroporation of the postnatal rodent forebrain. PLoS One 3:e1883.

Bovetti S, Bovolin P, Perroteau I, Puche AC (2007) Subventricular zonederived neuroblast migration to the olfactory bulb is modulated by matrix remodelling. Eur J Neurosci 25:2021-2033.

Bridges D, Rice AS, Egertová M, Elphick MR, Winter J, Michael GJ (2003) Localisation of cannabinoid receptor 1 in rat dorsal root ganglion using in situ hybridisation and immunohistochemistry. Neuroscience 119:803-812.

Brown JP, Couillard-Després S, Cooper-Kuhn CM, Winkler J, Aigner L, Kuhn HG (2003) Transient expression of doublecortin during adult neurogenesis. J Comp Neurol 467:1-10.

Chiaramello S, Dalmasso G, Bezin L, Marcel D, Jourdan F, Peretto P, Fasolo A, De Marchis S (2007) BDNF/ TrkB interaction regulates migration of SVZ precursor cells via PI3-K and MAP-K signalling pathways. Eur J Neurosci 26:1780-1790.

Conover JC, Doetsch F, Garcia-Verdugo JM, Gale NW, Yancopoulos GD, Alvarez-Buylla A (2000) Disruption of Eph/ephrin signaling affects migration and proliferation in the adult subventricular zone. Nat Neurosci 3:1091-1097.

Conti L, Pollard SM, Gorba T, Reitano E, Toselli M, Biella G, Sun Y, Sanzone S, Ying QL, Cattaneo E, Smith A (2005) Niche-independent symmetrical self-renewal of a mammalian tissue stem cell. PLoS Biol 3:e283.

Devane WA, Hanus L, Breuer A, Pertwee RG, Stevenson LA, Griffin G, Gibson D, Mandelbaum A, Etinger A, Mechoulam R (1992) Isolation 
and structure of a brain constituent that binds to the cannabinoid receptor. Science 258:1946-1949.

Diefenbach TJ, Latham VM, Yimlamai D, Liu CA, Herman IM, Jay DG (2002) Myosin 1c and myosin IIB serve opposing roles in lamellipodial dynamics of the neuronal growth cone. J Cell Biol 158:1207-1217.

Doherty P, Cohen J, Walsh FS (1990) Neurite outgrowth in response to transfected N-CAM changes during development and is modulated by polysialic acid. Neuron 5:209-219.

Etienne-Manneville S, Hall A (2001) Integrin-mediated activation of Cdc42 controls cell polarity in migrating astrocytes through PKCzeta. Cell 106:489-498.

Gao Y, Vasilyev DV, Goncalves MB, Howell FV, Hobbs C, Reisenberg M, Shen R, Zhang MY, Strassle BW, Lu P, Mark L, Piesla MJ, Deng K, Kouranova EV, Ring RH, Whiteside GT, Bates B, Walsh FS, Williams G, Pangalos MN, Samad TA, Doherty P (2010) Loss of retrograde endocannabinoid signaling and reduced adult neurogenesis in diacylglycerol lipase knock-out mice. J Neurosci 30:2017-2024.

Garzotto D, Giacobini P, Crepaldi T, Fasolo A, De Marchis S (2008) Hepatocyte growth factor regulates migration of olfactory interneuron precursors in the rostral migratory stream through Met-Grb2 coupling. J Neurosci 28:5901-5909.

Goings GE, Sahni V, Szele FG (2004) Migration patterns of subventricular zone cells in adult mice change after cerebral cortex injury. Brain Res 996:213-226.

Goncalves MB, Suetterlin P, Yip P, Molina-Holgado F, Walker DJ, Oudin MJ, Zentar MP, Pollard S, Yáñez-Muñoz RJ, Williams G, Walsh FS, Pangalos MN, Doherty P (2008) A diacylglycerol lipase-CB2 cannabinoid pathway regulates adult subventricular zone neurogenesis in an agedependent manner. Mol Cell Neurosci 38:526-536.

Gong JP, Onaivi ES, Ishiguro H, Liu QR, Tagliaferro PA, Brusco A, Uhl GR (2006) Cannabinoid CB2 receptors: immunohistochemical localization in rat brain. Brain Res 1071:10-23.

Gupta A, Sanada K, Miyamoto DT, Rovelstad S, Nadarajah B, Pearlman AL, Brunstrom J, Tsai LH (2003) Layering defect in p35 deficiency is linked to improper neuronal-glial interaction in radial migration. Nat Neurosci 6:1284-1291.

Hoover HS, Blankman JL, Niessen S, Cravatt BF (2008) Selectivity of inhibitors of endocannabinoid biosynthesis evaluated by activity-based protein profiling. Bioorg Med Chem Lett 18:5838-5841.

Hu H, Tomasiewicz H, Magnuson T, Rutishauser U (1996) The role of polysialic acid in migration of olfactory bulb interneuron precursors in the subventricular zone. Neuron 16:735-743.

Huang C (2010) Roles of E3 ubiquitin ligases in cell adhesion and migration. Cell Adh Migr 4:10-18.

Hurtado-Chong A, Yusta-Boyo MJ, Vergaño-Vera E, Bulfone A, de Pablo F, Vicario-Abejón C (2009) IGF-I promotes neuronal migration and positioning in the olfactory bulb and the exit of neuroblasts from the subventricular zone. Eur J Neurosci 30:742-755.

Jaffe AB, Hall A (2005) Rho GTPases: biochemistry and biology. Annu Rev Cell Dev Biol 21:247-269.

Jiang W, Zhang Y, Xiao L, Van Cleemput J, Ji SP, Bai G, Zhang X (2005) Cannabinoids promote embryonic and adult hippocampus neurogenesis and produce anxiolytic- and antidepressant-like effects. J Clin Invest 115:3104-3116.

Jin K, Xie L, Kim SH, Parmentier-Batteur S, Sun Y, Mao XO, Childs J, Greenberg DA (2004) Defective adult neurogenesis in CB1 cannabinoid receptor knockout mice. Mol Pharmacol 66:204-208.

Jordà MA, Verbakel SE, Valk PJ, Vankan-Berkhoudt YV, Maccarrone M, Finazzi-Agrò A, Löwenberg B, Delwel R (2002) Hematopoietic cells expressing the peripheral cannabinoid receptor migrate in response to the endocannabinoid 2-arachidonoylglycerol. Blood 99:2786-2793.

Joseph J, Niggemann B, Zaenker KS, Entschladen F (2004) Anandamide is an endogenous inhibitor for the migration of tumor cells and T lymphocytes. Cancer Immunol Immunother 53:723-728.

Kappeler C, Saillour Y, Baudoin JP, Tuy FP, Alvarez C, Houbron C, Gaspar P, Hamard G, Chelly J, Métin C, Francis F (2006) Branching and nucleokinesis defects in migrating interneurons derived from doublecortin knockout mice. Hum Mol Genet 15:1387-1400.

Kee N, Sivalingam S, Boonstra R, Wojtowicz JM (2002) The utility of Ki-67 and BrdU as proliferative markers of adult neurogenesis. J Neurosci Methods 115:97-105.

Keimpema E, Barabas K, Morozov YM, Tortoriello G, Torii M, Cameron G,
Yanagawa Y, Watanabe M, Mackie K, Harkany T (2010) Differential subcellular recruitment of monoacylglycerol lipase generates spatial specificity of 2-arachidonoyl glycerol signaling during axonal pathfinding. J Neurosci 30:13992-14007.

Koizumi H, Higginbotham H, Poon T, Tanaka T, Brinkman BC, Gleeson JG (2006) Doublecortin maintains bipolar shape and nuclear translocation during migration in the adult forebrain. Nat Neurosci 9:779-786.

Kokaia Z, Thored P, Arvidsson A, Lindvall O (2006) Regulation of strokeinduced neurogenesis in adult brain-recent scientific progress. Cereb Cortex 16 [Suppl 1]:i162-i167.

Lois C, García-Verdugo JM, Alvarez-Buylla A (1996) Chain migration of neuronal precursors. Science 271:978-981.

Long JZ, Li W, Booker L, Burston JJ, Kinsey SG, Schlosburg JE, Pavón FJ, Serrano AM, Selley DE, Parsons LH, Lichtman AH, Cravatt BF (2009) Selective blockade of 2-arachidonoylglycerol hydrolysis produces cannabinoid behavioral effects. Nat Chem Biol 5:37-44.

Lunn CA, Fine JS, Rojas-Triana A, Jackson JV, Fan X, Kung TT, Gonsiorek W, Schwarz MA, Lavey B, Kozlowski JA, Narula SK, Lundell DJ, Hipkin RW, Bober LA (2006) A novel cannabinoid peripheral cannabinoid receptorselective inverse agonist blocks leukocyte recruitment in vivo. J Pharmacol Exp Ther 316:780-788.

Maison P, Walker DJ, Walsh FS, Williams G, Doherty P (2009) BDNF regulates neuronal sensitivity to endocannabinoids. Neurosci Lett 467:90-94

Marín O, Valiente M, Ge X, Tsai LH (2010) Guiding neuronal cell migrations. Cold Spring Harb Perspect Biol 2:a001834.

Mechoulam R, Shohami E (2007) Endocannabinoids and traumatic brain injury. Mol Neurobiol 36:68-74.

Miller AM, Stella N (2008) CB2 receptor-mediated migration of immune cells: it can go either way. Br J Pharmacol 153:299-308.

Mulder J, Aguado T, Keimpema E, Barabás K, Ballester Rosado CJ, Nguyen L, Monory K, Marsicano G, Di Marzo V, Hurd YL, Guillemot F, Mackie K, Lutz B, Guzmán M, Lu HC, Galve-Roperh I, Harkany T (2008) Endocannabinoid signaling controls pyramidal cell specification and longrange axon patterning. Proc Natl Acad Sci U S A 105:8760-8765.

Murase S, Cho C, White JM, Horwitz AF (2008) ADAM2 promotes migration of neuroblasts in the rostral migratory stream to the olfactory bulb. Eur J Neurosci 27:1585-1595.

Nasrallah IM, McManus MF, Pancoast MM, Wynshaw-Boris A, Golden JA (2006) Analysis of non-radial interneuron migration dynamics and its disruption in Lis1 + / - mice. J Comp Neurol 496:847-858.

Ono K, Tomasiewicz H, Magnuson T, Rutishauser U (1994) N-CAM mutation inhibits tangential neuronal migration and is phenocopied by enzymatic removal of polysialic acid. Neuron 13:595-609.

Ortar G, Bisogno T, Ligresti A, Morera E, Nalli M, Di Marzo V (2008) Tetrahydrolipstatin analogues as modulators of endocannabinoid 2-arachidonoylglycerol metabolism. J Med Chem 51:6970-6979.

Palazuelos J, Aguado T, Egia A, Mechoulam R, Guzmán M, Galve-Roperh I (2006) Non-psychoactive CB2 cannabinoid agonists stimulate neural progenitor proliferation. FASEB J 20:2405-2407.

Paratcha G, Ibáñez CF, Ledda F (2006) GDNF is a chemoattractant factor for neuronal precursor cells in the rostral migratory stream. Mol Cell Neurosci 31:505-514

Patinkin, D, Milman, G, Breuer, A, Fride, E, Mechoulam, R (2008) Endocannabinoids as positive or negative factors in hematopoietic cell migration and differentiation. Eur J Pharmacol 595:1-6.

Pertwee RG (2006) The pharmacology of cannabinoid receptors and their ligands: an overview. Int J Obes 30 [Suppl 1]:S13-S18.

Pollard SM, Conti L, Sun Y, Goffredo D, Smith A (2006) Adherent neural stem (NS) cells from fetal and adult forebrain. Cereb Cortex 16 [Suppl 1]:i112-i120.

Preet A, Ganju RK, Groopman JE (2008) Delta9-Tetrahydrocannabinol inhibits epithelial growth factor-induced lung cancer cell migration in vitro as well as its growth and metastasis in vivo. Oncogene 27:339-346.

Rouzer, CA, Ghebreselasie, K, Marnett, LJ (2002) Chemical stability of 2 -arachidonylglycerol under biological conditions. Chem Phys Lipids 119:69-82.

Schaar BT, McConnell SK (2005) Cytoskeletal coordination during neuronal migration. Proc Natl Acad Sci U S A 102:13652-13657.

Straiker A, Hu SS, Long JZ, Arnold A, Wager-Miller J, Cravatt BF, Mackie K (2009) Monoacylglycerol lipase limits the duration of endocannabinoid- 
mediated depolarization-induced suppression of excitation in autaptic hippocampal neurons. Molecular pharmacology 76:1220-1227.

Tomasiewicz H, Ono K, Yee D, Thompson C, Goridis C, Rutishauser U, Magnuson T (1993) Genetic deletion of a neural cell adhesion molecule variant (N-CAM-180) produces distinct defects in the central nervous system. Neuron 11:1163-1174.

Twitchell W, Brown S, Mackie K (1997) Cannabinoids inhibit N- and P/Qtype calcium channels in cultured rat hippocampal neurons. J Neurophysiol 78:43-50.

Ward ME, Rao Y (2005b) Investigations of neuronal migration in the central nervous system. Methods Mol Biol 294:137-156.

Ward ME, Jiang H, Rao Y (2005a) Regulated formation and selection of neuronal processes underlie directional guidance of neuronal migration. Mol Cell Neurosci 30:378-387.

Wichterle H, Garcia-Verdugo JM, Alvarez-Buylla A (1997) Direct evidence for homotypic, glia-independent neuronal migration. Neuron 18:779-791.

Williams EJ, Walsh FS, Doherty P (2003) The FGF receptor uses the endocannabinoid signaling system to couple to an axonal growth response. J Cell Biol 160:481-486.

Witting A, Chen L, Cudaback E, Straiker A, Walter L, Rickman B, Möller T,
Brosnan C, Stella N (2006) Experimental autoimmune encephalomyelitis disrupts endocannabinoid-mediated neuroprotection. Proc Natl Acad Sci U S A 103:6362-6367.

Yoshida T, Fukaya M, Uchigashima M, Miura E, Kamiya H, Kano M, Watanabe M (2006) Localization of diacylglycerol lipase-alpha around postsynaptic spine suggests close proximity between production site of an endocannabinoid, 2-arachidonoyl-glycerol, and presynaptic cannabinoid $\mathrm{CB}_{1}$ receptor. J Neurosci 26:4740-4751.

Zhang H, Vutskits L, Pepper MS, Kiss JZ (2003) VEGF is a chemoattractant for FGF-2-stimulated neural progenitors. J Cell Biol 163:13751384.

Zhang RL, LeTourneau Y, Gregg SR, Wang Y, Toh Y, Robin AM, Zhang ZG, Chopp M (2007) Neuroblast division during migration toward the ischemic striatum: a study of dynamic migratory and proliferative characteristics of neuroblasts from the subventricular zone. J Neurosci 27:3157-3162.

Zhang R, Zhang Z, Wang L, Wang Y, Gousev A, Zhang L, Ho KL, Morshead C, Chopp M (2004) Activated neural stem cells contribute to strokeinduced neurogenesis and neuroblast migration toward the infarct boundary in adult rats. J Cereb Blood Flow Metab 24:441-448. 